\title{
Wiedza i opinie kobiet na temat wybranych aspektów nietrzymania moczu
}

\section{Women's knowledge and opinions on selected aspects of urinary incontinence}

\author{
BOŻENA WOJTYCKAํㅜ, BEATA HAOR² \\ ${ }^{1}$ Centrum Diagnostyczno-Lecznicze Barska we Włocławku \\ ${ }^{2}$ Instytut Nauk o Zdrowiu, Państwowa Uczelnia Zawodowa we Włocławku
}

DOI: http://dx.doi.org/10.21784/lwP.2020.002

ISSN: 2451-1846

\section{Streszczenie:}

Wstęp. Terapia i profilaktyka nietrzymania moczu powinna być ukierunkowana na działania edukacyjne realizowane wobec członków zespołu terapeutycznego, chorych i ich rodzin oraz całego społeczeństwa.

Cel. Celem pracy jest analiza wiedzy i opinii kobiet na temat wybranych aspektów nietrzymania moczu.

Materiał i metody. Badanie dotyczyło 100 pacjentek z nietrzymaniem moczu. Wykorzystano metodę sondażu diagnostycznego i technikę ankietowania.

Wyniki. W badaniach własnych respondentki potwierdziły, że epizody nietrzymania moczu obserwowane są częściej w starszych grupach wiekowych kobiet. Posiadały także zróżnicowaną wiedzę na temat przyczyn, czynników ryzyka, metod diagnostyki i terapii NTM. Większość badanych potwierdziła wpływ choroby na sferę życia seksualnego, aktywność zawodową oraz życie rodzinne. Najmniejszy odsetek respondentek podkreślił wpływ NTM na sferę życia społecznego. Ponad połowa kobiet wskazuje, że posiada znikomą wiedzę nt. profilaktyki nietrzymania moczu. Zdecydowana większość badanych deklaruje, że chciałaby zdecydowanie poszerzyć swoją wiedzę na ten temat. Kobiety zdecydowanie najczęściej 
podawały, że powszechnym źródłem wiedzy na temat NTM jest informacja uzyskana od ginekologa, urologa, lekarza specjalisty oraz dane z Internetu.

Wnioski. 1. Kobiety z nietrzymaniem moczu wykazują zróżnicowany poziom wiedzy na temat wybranych aspektów schorzenia. 2. Kobiety potwierdzają niedostatek wiedzy na temat wybranych aspektów nietrzymania moczu a zarazem wykazują gotowość do jej uzupełniania.

Słowa kluczowe: nietrzymanie moczu, kobieta, wiedza

\begin{abstract}
:
Introduction. The therapy and prevention of urinary incontinence NTM should be focused on educational activities carried out for members of the therapeutic team, patients and their families, and the entire society.
\end{abstract}

Aim. The aim of the study is to analyse women's knowledge and opinions on selected aspects of urinary incontinence.

Material and methods. The study involved 100 patients with urinary incontinence. A diagnostic survey method and a survey technique were used.

Results. In their own research, the respondents confirmed that urinary incontinence episodes are more often observed in older age groups of women. They also had a varied knowledge of the causes, risk factors, diagnostic methods and NTM therapy. Most of the respondents confirmed the impact of the disease on the sphere of sexual life, professional activity and family life. The smallest percentage of respondents emphasized the impact of NTM on the sphere of social life. More than half of the women indicate that they have little knowledge about the prevention of urinary incontinence. The vast majority of respondents declare that they would like to definitely expand their knowledge on this subject. Women most often stated that the common source of knowledge about NTM is information obtained from a gynecologist, urologist, specialist doctor and data from the Internet.

Conclusions. 1 . Women with urinary incontinence show a different level of knowledge about selected aspects of the disease. 2. Women confirm insufficient knowledge about selected aspects of urinary incontinence and at the same time show readiness to supplement it. 
Keywords: urinary incontinence, woman, knowledge

\section{Wstęp}

Nietrzymaniem moczu (NTM) wg Międzynarodowego Towarzystwa ds. Kontynencji (ang. International Continence Society - ICS) określa się każdy epizod niekontrolowanej utraty moczu. Zwraca się na niego uwagę niezależnie od tego, czy jest on przyczyną problemów higienicznych lub społecznych [1, 2,3]. NTM uznawane jest za chorobę społeczną $z$ uwagi na powszechność występowania w społeczeństwie (>5\%), podobnie jak choroby układu sercowo-naczyniowego, nowotwory, alkoholizm, otyłość $[4,5,6]$.

Terapia i profilaktyka NTM z uwagi na jego wieloaspektowe uwarunkowania i konsekwencje, powinna być ukierunkowana na działania edukacyjne adresowane do członków zespołu terapeutycznego, chorych i ich rodzin oraz całego społeczeństwa. Niedostatek programów profilaktycznych przekłada się niedostateczne przygotowanie przedstawicieli personelu medycznego do wdrażania odpowiednich działań profilaktycznych, adresowanych szczególnie wobec pacjentów z grupy ryzyka NTM. Z kolei wśród chorych nieodpowiedni zasób wiedzy prowadzi do utrwalania się przekonania, że jest to przykra dolegliwość towarzysząca fizjologii procesu starzenia, z którą należy się pogodzić $[7,8]$. 


\section{Cel}

Celem pracy jest analiza wiedzy i opinii kobiet na temat wybranych aspektów nietrzymania moczu.

\section{Materiał i metody}

W badaniu wzięło udział 100 pacjentek Centrum Diagnostyczno-Leczniczego „Barska" we Włocławku z potwierdzonym nietrzymaniem moczu. Były to kobiety bez zaburzeń poznawczych, $\mathrm{z}$ dobrą sprawnością funkcjonalną umożliwiającą samodzielne wypełnienie kwestionariusza.

Rozpiętość wieku respondentek mieściła się w granicach od 30 do 81 lat. Największą grupę stanowiły kobiety między 41 50 rokiem życia (44\%- 44 osoby). Powyżej 61 roku życia było $26 \%$ badanych (26 osób) a w wieku 51-60 lat - 17\% pacjentek (17 osób). Najmniejszą grupę stanowiły kobiety między 30-40 rokiem życia (13\%-13 osób). Zdecydowana większość badanych (61\%-61 osób) mieszka w mieście a 39\% (39 osób) to mieszkanki wsi. Najwięcej respondentek posiadało wykształcenie wyższe (46\%- 46 osób). Wykształceniem zawodowym legitymowało się 29\% pacjentek (29 osób) a podstawowym 21\% kobiet (21 osób). Tylko 4\% badanych (4 osoby) posiadało wykształcenie średnie. Zdecydowaną większość respondentek stanowiły mężatki (68\%- 68 osób). W badanej grupie było 18\% wdów (18 osób), 13\% panien (13 osób)a 1 osoba (1\%) była rozwiedziona. Większość kobiet (81\%-81 osób) mieszka wraz z rodziną, opiekunami a 19\% (19 osób) samotnie prowadzi gospodarstwo domowe. Wśród przyczyn aktualnej wizyty w placówce większość respondentek 
(45\%- 45 osób) wskazało zgłoszenie się na badanie urodynamiczne a 30\% badanych (30 osób) - przeprowadzenie badania ginekologicznego. Najmniej ankietowanych $(25 \%-25$ osób) przyjęto do oddziału w celu wykonania zabiegu operacyjnego.

W aktualnych badaniach wykorzystano metodę sondażu diagnostycznego, technikę ankietowania oraz kwestionariusz ankiety własnego autorstwa.

Zebrany materiał wprowadzono do specjalnie opracowanej na potrzeby badań bazy danych programu Excel. Wszystkie obliczenia wykonano za pomocą pakietu statystycznego SPSS Statistics 21,0. Wyniki poddano je analizie opisowej, graficznej oraz statystycznej. Przedstawione w opracowaniu dane mają charakter wstępny prezentujący wybrane aspekty wiedzy respondentek na temat nietrzymania moczu w ujęciu liczbowym i procentowym.

\section{Wyniki}

W tabeli 1 zaprezentowano wiedzę badanych nt. liczby kobiet $\mathrm{z}$ nietrzymaniem moczu $\mathrm{w}$ zależności od przedziału wiekowego.

Tabela 1.Wiedza badanych nt. wieku kobiet, u których występuje nietrzymanie moczu

\begin{tabular}{|l|r|c|}
\hline $\begin{array}{l}\text { Największa liczba kobiet z nietrzymaniem moczu występuje w } \\
\text { przedziale wiekowym: }\end{array}$ & $\mathrm{n}$ & \multicolumn{1}{c|}{$\%$} \\
\hline Między 35-45 r.ż. & 11 & 11 \\
\hline Między 45-55 r.ż. & 47 & 47 \\
\hline Powyżej 55 r.ż. & 30 & 30 \\
\hline Powyżej 70 r.ż. & 12 & 12 \\
\hline
\end{tabular}

Źródło: wyniki badań własnych. 
W opinii zdecydowanej większości badanych (47\% - 47 osób) najczęściej z problemem nietrzymania moczu zmagają się kobiety $\mathrm{w}$ przedziale wiekowym 45-55 lat. Natomiast 30\% pacjentek (30 osób) uważa, że NTM dotyczy kobiet powyżej 55 roku życia. Zdaniem 11\% badanych (11 osób) problem ten dotyczy osób między 35-45 rokiem życia. Natomiast $12 \%$ respondentek (12 osób) twierdzi, że NTM występuje po 70 roku życia.

W tabeli 2 zaprezentowano wiedzę pacjentek nt. czynników socjodemograficznych i genetycznych, które mogą wpływać na NTM.

\section{Tabela 2.Wiedza badanych nt. czynników socjodemograficznych i genetycznych, które mogą wpływać na NTM.}

\begin{tabular}{|l|r|c|}
\hline Czy uważa Pani, że na nietrzymanie moczu wpływa: & $\mathrm{n}$ & $\%$ \\
\hline Miejsce zamieszkania & 23 & 13,00 \\
\hline Wykształcenie & 21 & 11,90 \\
\hline Status związku, w którym pozostaje kobieta & 26 & 14,70 \\
\hline Aktywność seksualna & 63 & 35,60 \\
\hline Czynniki genetyczne & 44 & 24,90 \\
\hline
\end{tabular}

Źródło: wyniki badań własnych.

Zdecydowana większość kobiet (35,6\%-63 osób) uważa, że wpływ na nietrzymanie moczu ma aktywność seksualna oraz czynniki genetyczne $(24,9 \%$ - 44 osoby). Z kolei $14,7 \%$ respondentek (26 osób) wskazało na status związku, w którym 
pozostaje kobieta a 13\% (23 osoby) podało jako czynnik NTM miejsce zamieszkania. Najmniejsza grupa badanych $(11,9 \%-21$ osób) wskazała na wpływ wykształcenia.

W tabeli 3. zaprezentowano wiedzę kobiet nt. czynników wynikających ze stylu życia, pracy, wywiadu położniczego, chorób współistniejących, wpływających na nietrzymanie moczu.

Tabela 3. Wiedza badanych nt. czynników wynikających ze stylu życia, pracy, wywiadu położniczego, chorób współistniejących, wpływających na nietrzymanie moczu.

\begin{tabular}{|l|r|r|}
\hline Jakie czynniki wpływają na NTM? & $\mathrm{n}$ & \multicolumn{1}{|c|}{$\%$} \\
\hline Ilość porodów & 70 & 17,90 \\
\hline Rodzaj porodów & 64 & 16,40 \\
\hline Charakter wykonywanej pracy & 55 & 14,10 \\
\hline Styl życia & 54 & 13,80 \\
\hline Choroby towarzyszące & 46 & 11,80 \\
\hline Występowanie infekcji układu moczowego & 61 & 15,60 \\
\hline Otyłość & 41 & 10,50 \\
\hline
\end{tabular}

Źródło: wyniki badań własnych.

W grupie czynników, które najczęściej wskazywały kobiety jako przyczynę NTM były: ilość porodów (17,9\% - 70 osób), ich charakter (16,4\% - 64 osoby) oraz infekcje układu moczowego (15,6\% - 61 osób). Wśród kolejnych czynników respondentki podawały charakter wykonywanej pracy $(14,1 \%$ 55 osób) oraz styl życia (13,8\% - 54 osób). W najmniejszym zakresie upatrywały przyczyn NTM w obecności chorób 
towarzyszących $(11,8 \%$ - 46 osób) oraz otyłości $(10,5 \%-41$ osób).

W tabeli 4. zaprezentowano wiedzę kobiet nt. badań diagnostycznych stosowanych w NTM.

Tabela 4. Wiedza badanych nt. badań diagnostycznych w nietrzymania moczu.

\begin{tabular}{|l|r|r|}
\hline $\begin{array}{l}\text { Jakie badania Pani zdaniem potwierdzają występowanie } \\
\text { nietrzymania moczu oraz są pomocne w określeniu jego } \\
\text { stopnia? }\end{array}$ & \multicolumn{1}{c|}{ n } & \multicolumn{1}{c|}{$\%$} \\
\hline USG jamy brzusznej & 36 & 16,70 \\
\hline Urografia & 47 & 21,90 \\
\hline Badanie urodynamiczne & 90 & 41,90 \\
\hline Badanie ogólne moczu & 31 & 14,40 \\
\hline Badanie chemiczne krwi & 11 & 5,10 \\
\hline
\end{tabular}

Źródło: wyniki badań własnych.

Zdecydowana większość kobiet (41,9\% - 90 osób) wskazało badanie urodynamiczne, jako najbardziej wiarygodne badanie w diagnostyce NTM. Ponadto respondentki wskazywały także na urografię $(21,9 \%$ - 47 osób), USG jamy brzusznej (16,7\% - 36 osób) oraz badanie ogólne moczu (14,4\% - 31 osób). Najmniej wskazań dotyczyło badań chemicznych krwi (5,1\% - 11 osób).

W tabeli 5 zaprezentowano wiedzę badanych nt. metod leczenia NTM. 
Tabela 5. Wiedza badanych nt. metod terapii nietrzymania moczu.

\begin{tabular}{|l|r|r|}
\hline Leczenie nietrzymania moczu obejmuje: & $\mathrm{n}$ & \multicolumn{1}{|c|}{$\%$} \\
\hline Psychoterapię & 23 & 7,40 \\
\hline Leczenie farmakologiczne & 64 & 20,60 \\
\hline Leczenie operacyjne (chirurgiczne) & 83 & 26,80 \\
\hline Trening pęcherza moczowego & 63 & 20,30 \\
\hline Ćwiczenie mięśni Kegla & 58 & 18,70 \\
\hline Stosowanie dopochwowych krążków & 19 & 6,10 \\
\hline
\end{tabular}

Źródło: wyniki badań własnych.

Większość kobiet za najskuteczniejszą metodę leczenia NTM uważa leczenie operacyjne (26,8\% - 83 osoby), leczenie farmakologiczne $(20,6 \%$ - 64 osób), trening pęcherza moczowego (20,3\% - 63 osób) oraz ćwiczenia mięśni Kegla (18,7\% - 58 osób). Psychoterapię jako metodę leczenia podało $7,4 \%$ respondentek (23 osoby) a 6,1\% (19 osób) - stosowanie krążków dopochwowych.

W tabeli 6 zaprezentowano wiedzę kobiet nt. dostępnych źródeł wiedzy na temat NTM. 
Tabela 6. Wiedza badanych nt. źródeł wiedzy na temat nietrzymania moczu.

\begin{tabular}{|l|r|r|}
\hline $\begin{array}{l}\text { Najbardziej powszechnym źródłem wiedzy na temat } \\
\text { nietrzymania moczu jest: }\end{array}$ & \multicolumn{1}{c|}{$\mathrm{n}$} & \multicolumn{1}{c|}{$\%$} \\
\hline Internet & 67 & 20,50 \\
\hline Telewizja & 29 & 8,90 \\
\hline Prasa & 35 & 10,70 \\
\hline Lekarz rodzinny & 48 & 14,70 \\
\hline Ginekolog, urolog, lekarz specjalista & 74 & 22,60 \\
\hline Pielęgniarka, położna & 54 & 16,50 \\
\hline Rodzina, przyjaciele & 20 & 6,10 \\
\hline
\end{tabular}

Źródło: wyniki badań własnych.

Respondentki zdecydowanie najczęściej (22,6\% - 74 osoby) wskazują, że powszechnym źródłem wiedzy nt. NTM jest informacja uzyskana od ginekologa, urologa, lekarza specjalisty oraz dane z Internetu (20,5\% - 67 osób). Następnie kobiety wskazywały na informacje otrzymane od pielęgniarki/położnej (16,5\% - 54 osoby) i lekarza rodzinnego (14,7\% - 48 osób). Jako źródło wiedzy nt. NTM badane podają także prasę (10,7\% - 35 osób) i telewizję (8,9\% - 29 osób). Natomiast w najmniejszym zakresie respondentki wskazywały na informacje uzyskane od rodziny, przyjaciół (6,1\% - 20 osób).

W tabeli 7 zaprezentowano opinie badanych nt. sfery życia, na które wpływa NTM. 
Tabela 7. Opinia badanych nt. sfer życia, na które ma wypływ nietrzymanie moczu.

\begin{tabular}{|l|c|c|}
\hline Na jakie sfery życia Pani zdaniem wpływa nietrzymanie moczu? & $\mathrm{n}$ & $\%$ \\
\hline Rodzinną & 68 & 24,90 \\
\hline Społeczną & 56 & 20,50 \\
\hline Seksualną & 77 & 28,20 \\
\hline Zawodową & 72 & 26,40 \\
\hline
\end{tabular}

Źródło: wyniki badań własnych.

Zdaniem większości respondentek NTM zdecydowanie wpływa na sferę życia seksualnego (28,2\% - 77 osób) i aktywność zawodową (26,4\% - 72 osoby). Kolejne wskazanie dotyczyło życia rodzinnego (24,9\% - 68 osób). Najmniejszy odsetek badanych podkreślił wpływ NTM na sferę życia społecznego (20,5\% - 56 osób).

W tabeli 8 zaprezentowano opinię respondentek na temat swojej wiedzy w zakresie profilaktyki NTM.

Tabela 8. Samoocena badanych nt. wiedzy dotyczącej profilaktyki nietrzymania moczu.

\begin{tabular}{|l|r|r|}
\hline $\begin{array}{l}\text { Jak ocenia Pani swoją wiedzę na temat profilaktyki } \\
\text { nietrzymania moczu? }\end{array}$ & \multicolumn{1}{c|}{$\mathrm{n}$} \\
\hline Nie posiadam żadnej wiedzy & 10 & 10 \\
\hline Posiadam znikomą wiedzę & 55 & 55 \\
\hline Posiadam dostateczną wiedzę & 30 & 30 \\
\hline Posiadam dużą wiedzę & 5 & 5 \\
\hline Ogółem & 100 & 100 \\
\hline
\end{tabular}

Źródło: wyniki badań własnych. 
Ponad połowa respondentek wskazuje, że posiada znikomą wiedzę nt. profilaktyki nietrzymania moczu (55\% - 55 osób). Dostateczny zasób wiedzy w tym zakresie podało $30 \%$ kobiet (30 osób) a jego zupełny brak 10\% badanych (10 osób). Tylko 5\% respondentek (5 osób) deklaruje, że posiada dużą wiedzę nt. profilaktyki nietrzymania moczu.

W tabeli 9 zaprezentowano opinię kobiet nt. gotowości poszerzania wiedzy na temat profilaktyki NTM.

\section{Tabela 9. Opinie badanych nt. gotowości poszerzania wiedzy na temat profilaktyki nietrzymania moczu.}

\begin{tabular}{|l|r|r|}
\hline $\begin{array}{l}\text { Czy planuje Pani poszerzyć swoje wiadomości na temat } \\
\text { profilaktyki nietrzymania moczu? }\end{array}$ & \multicolumn{1}{c|}{$\mathrm{n}$} & \multicolumn{1}{c|}{$\%$} \\
\hline Zdecydowanie tak & 48 & 48 \\
\hline Raczej tak & 46 & 46 \\
\hline Raczej nie & 6 & 6 \\
\hline Ogółem & 100 & 100 \\
\hline
\end{tabular}

Źródło: wyniki badań własnych.

Większość respondentek deklaruje, że chciałaby zdecydowanie poszerzyć swoją wiedzę nt. profilaktyki nietrzymania moczu (48\% - 48 osób) lub raczej tak postąpić (46\% - 46 osób). Tylko 6\% kobiet (6 osób) podało, że raczej nie będzie podejmować takich działań.

\section{Dyskusja}

Jak wynika z przeprowadzonych badań własnych kobiety z NTM prezentują zróżnicowany poziom wiedzy na temat 
wybranych aspektów schorzenia. Prezentowane przez nich opinie potwierdzają niedostatek wiedzy w tym zakresie a zarazem respondentki wykazują gotowość do jej uzupełniania.

Nietrzymanie moczu dotyczy zarówno kobiet, jak i mężczyzn niezależnie od wieku. Niemniej jednak kobiety chorują dwa razy częściej $\mathrm{z}$ uwagi na funkcje biologiczne i budowę anatomiczną. Powyższa sytuacja ulega nasileniu w miarę zaawansowania wieku bowiem pierwszy szczyt zachorowalności przypada na okres około menopauzalny. Natomiast po 65 roku życia obserwuje się systematyczny wzrost występowania nietrzymania moczu $[3,4,9]$. W badaniach własnych respondentki potwierdziły, że epizody nietrzymania moczu obserwowane są częściej w starszych grupach wiekowych kobiet.

W grupie przyczyn i czynników ryzyka NTM najczęściej wyróżnia się: płeć, wiek, rasę, przebyte ginekologiczne zabiegi operacyjne, nadwagę lub otyłość, porody siłami natury, masę urodzeniową dziecka, liczbę i charakter porodu, elementy stylu życia, uwarunkowania genetyczne, menopauzę oraz choroby przewlekłe takie jak np. cukrzyca, udar mózgu, POCHP [3,10,11,12,13]. Schorzenie częściej rozpoznaje się także u osób pracujących fizycznie, z niską lub bardzo wysoką aktywnością fizyczną, $\mathrm{z}$ nawracającymi infekcjami układu moczowego, z rodzinnym wywiadem NTM $[6,14,15,16,17]$. W badaniach własnych respondentki potwierdziły znajomość wybranych przyczyn i czynników ryzyka schorzenia.

W większości przypadków nietrzymanie moczu niezależnie od wieku chorych jest uleczalne. Z uwagi jednak 
na progresję objawów, bez wczesnej diagnostyki, leczenia i profilaktyki dochodzi do pogłębienia zaburzeń. Najbardziej skuteczna jest terapia, która zostaje wdrożona w ciągu pierwszych czterech lat od wystąpienia pierwszych objawów $[8,18]$. W grupie metod terapii wymienia się farmakoterapię, leczenie operacyjne, metody fizjoterapeutyczne (trening mięśni dna miednicy, elektrostymulację, biofeedback, technikę ETS i magnetoterapię) [2,8]. W badaniach własnych respondentki potwierdziły zróżnicowaną wiedzę nt. metod diagnostyki i terapii NTM.

NTM z związku z uciążliwością i długotrwałością objawów istotnie przekłada się na obniżenie jakości życia kobiet. Potwierdzają to wyniki badań Bidzan, która wykazała, że choroba doprowadziła do zmian w sferze rodzinnego funkcjonowania kobiet tj. trybie i stylu życia rodziny, obniżeniu aktywności seksualnej, obciążeniu budżetu domowego dodatkowymi wydatkami. Kobiety podkreślały także zmiany w sferze funkcjonowania zawodowego w zakresie planów zawodowych czy nawet rezygnacji z pracy oraz $w$ sferze społecznej, co wynikało z ograniczenia kontaktów społecznych $[8,19]$. Natomiast w badaniu Dutkiewicza i Kapusty wykazano poza alienacją w życiu społecznych, redukcję aktywności zawodowej oraz skłonność kobiet do zaburzeń emocjonalnych, wynikających z lęku i wstydu przed epizodami przemoczenia ubrań $[8,20]$. W badaniach własnych większość respondentek potwierdziło wpływ NTM na sferę życia seksualnego, aktywność zawodową oraz życie rodzinne. Najmniejszy odsetek badanych podkreślił wpływ choroby sferę życia społecznego. 
Niedostatek wiedzy na temat NTM wpływa na to, że kobiety ignorują objawy i nie dążą do wczesnej diagnostyki, terapii i profilaktyki zaburzeń. W badaniach PołockiejMolińskiej i wsp. respondentki najczęściej oceniały swoją wiedzę na temat profilaktyki nietrzymania moczu jako dobrą (39\%) i bardzo dobrą (18\%). Najmniejszy odsetek kobiet (13\%) wskazywał na bardzo małą wiedzę [16]. Z kolei w badaniach Cichońskiej i wsp. stwierdzono, że tylko 18\% kobiet posiada wysoką świadomość na temat nietrzymania moczu, 52\% nie wie, jak można leczyć chorobę a 30\% badanych wskazało na niewielką wiedzę na temat NTM $[16,21]$. W badaniach własnych ponad połowa respondentek wskazuje, że posiada znikomą wiedzę nt. profilaktyki nietrzymania moczu. Dostateczny zasób wiedzy w tym zakresie podało 30\% kobiet a jego zupełny brak 10\% badanych. Tylko 5\% respondentek deklaruje, że posiada dużą wiedzę nt. profilaktyki nietrzymania moczu. Niemniej jednak zdecydowana większość badanych deklaruje, że chciałaby zdecydowanie poszerzyć swoją wiedzę na ten temat lub raczej tak postąpić. Tylko $6 \%$ podało, że raczej nie będzie podejmować takich działań.

Wiarygodne źródła informacji nt. NTM mają zazwyczaj charakter naukowy i są one mniej dostępne, w porównaniu do nieprofesjonalnych źródeł informacji. Z kolei uzyskiwanie danych $\mathrm{w}$ ramach konsultacji $\mathrm{z}$ profesjonalistami $\mathrm{z}$ systemu ochrony zdrowia bywa utrudnione, krępujące a czasami także niezrozumiałe [3]. W badaniach Dereweckiego i wsp. ponad połowa respondentów wskazała, że w Polsce dostęp do informacji o nietrzymaniu moczu jest utrudniony $[3,22]$. 
Natomiast w badaniach Gugały i wsp. tego zdania było $90 \%$ badanych $[3,23]$. W badaniach własnych respondentki zdecydowanie najczęściej podawały, że powszechnym źródłem wiedzy nt. NTM jest informacja uzyskana od ginekologa, urologa, lekarza specjalisty oraz dane z Internetu. W następnej kolejności kobiety wskazywały na dane otrzymane od pielęgniarki/położnej, lekarza rodzinnego. Źródłem wiedzy była także prasa i telewizja a w najmniejszym zakresie informacje uzyskane od rodziny, przyjaciół.

\section{Wnioski}

1. Kobiety $\mathrm{z}$ nietrzymaniem moczu prezentują zróżnicowany poziom wiedzy na temat wybranych aspektów schorzenia.

2. Kobiety potwierdzają niedostatek wiedzy na temat wybranych aspektów nietrzymania moczu a zarazem wykazują gotowość do jej uzupełniania.

\section{Zalecenia dla praktyki pielęgniarskiej}

Pielęgniarki sprawujące opiekę nad pacjentkami z nietrzymaniem moczu poza rozpoznaniem ich wieloaspektowych problemów, powinny systematycznie doskonalić zasób swojej wiedzy i kompetencji w zakresie prowadzenia skutecznej edukacji chorych w ramach ich przygotowania do samoopieki.

\section{Bibliografia/Bibliography:}

1. Abrams P., Cardozo L., Fall M., Griffiths D., Rosier P., Ulmsten U. et al. The standardisation of terminology in lower urinary tract function: report 
from the standardization sub-committee of the International Continence Society. Urology. 2003;61(1):37-49.

2. Weber-Rajek M., Bułatowicz I., Radzimińska A., Strojek K., Goch A., Żukow W. Ocena skuteczności metod fizykalnych w leczeniu nietrzymania moczu u kobiet - przegląd badań. J Education Health Sport. 2015;5(3):11-34.

3. Bakalczuk G., Madej A., Lewczuk J., Makara-Studzińska M., Wdowiak E., Lewicka M. et al. Stan wiedzy kobiet na temat nietrzymania moczu. Medycyna Ogólna i Nauki o Zdrowiu. 2016;22(4):277-281.

4. Bujanowska-Fedak M., Steciwko A. Nietrzymanie moczu w praktyce lekarza rodzinnego. W: Rechberger T.(red.). Uroginekologia Praktyczna. BiFolium, Lublin 2007:139-147.

5. Adamczuk J., Kraczkowski J.J., Robak M.J., Żurawska vel Dziurawiec K. Czy nietrzymanie moczu to choroba cywilizacyjna? Probl Hig Epidemiol. 2011; 92(3):382-386.

6. Barnaś E., Barańska E., Gawlik B., Zych B. Czynniki najbardziej wpływające na jakość życia kobiet z nietrzymaniem moczu. Hygeia Public Health. 2015; 50(4):643-648.

7. Radziszewski P. Dostępność badań urodynamicznych w Polsce. Kwartalnik NTM. 2000; 3(30):15-16.

8. Klimaszewska K. Społeczny aspekt nietrzymania moczu Pielęgniarstwo XXI wieku. 2017; vol.16, 3(60):57-61.

9. Adamiak A, Jankiewicz K. Epidemiologia nietrzymania moczu. W: Rechberger T (red.), Nietrzymanie moczu i zaburzenia statyki dna miednicy u kobiet. Termedia Wydawnictwo Medyczne, Poznań 2009; 1925. 
10. Dutkiewicz S., Kapusta K. Nietrzymanie moczu a czynniki ryzyka i jakość życia kobiet w Zakładzie Opiekuńczo-Leczniczym w Kielcach. Prz Menopauzalny. 2011;6:493-499.

11. Miękoś E., Sosnowski M., Zydek C. Czynniki ryzyka występowania i zapobieganie nietrzymaniu moczu u kobiet. Prz Menopauzalny. 2004;5: 43-49.

12. Hart M.L., Izeta A., Herdera-Imbroda B., Amend B., Brinchmann J.E. Cell Therapy for Stress Urinary Incontinence. Tissue Eng Part B Rev 2015.

13. Rincón Ardila 0. Prevalence and risk factors for urinary incontinence among young women consulting in primary care. Rev Med Chil. 2015; 143(2):203-212.

14.Wróbel R, Kremska A, Kołodziej B, Barnaś E. Ocena częstości występowania objawów nietrzymania moczu w populacji kobiet po 40 . roku życia. Prz Med Uniw Rzesz Inst Leków. 2013,1:40-49.

15. Iwanowicz-Palus G.J., Stadnicka G., Włoszczak-Szubzda A. Medical and psychosocial factors conditioning development of stress urinary incontinence (SUI). Ann Agric Environ Med. 2013, 20(1):135-139.

16. Połocka-Molińska M., Jakóbczak B., Plagens-Rotman K. Wpływ nietrzymania moczu na jakość życia kobiet. Polski Przegląd Nauk o Zdrowiu. 2017; 2 (51):161-167.

17. Piechota E, Baranowski W. Nietrzymanie moczu u kobiet. Pediatria i Medycyna Rodzinna. 2006; 2(3):163-175.

18. Koszla M. Fizjoterapia szansą dla pacjentek z NTM. Kwartalnik NTM. 2006;1:4.

19. Bidzan M. Jakość życia pacjentek z różnym stopniem nasilenia wysiłkowego nietrzymania moczu. Impuls, Kraków 2008:33. 
20. Dutkiewicz S., Kapusta K. Nietrzymanie moczu a czynniki ryzyka i jakość życia kobiet w Zakładzie Opiekuńczo- Leczniczym w Kielcach. Prz. Menopauz. 2011;6:493-499.

21.Cichońska M., Maciąg D., Zboina B., Latawiec I., Krawczyk W. Ocena stanu wiedzy kobiet na temat nietrzymania moczu. Zdrowie Dobrostan. 2013;4:45-64.

22.Derewiecki T., Mroczek M., Majcher P., Chruściel P. Znaczenie problemu nietrzymania moczu wśród kobiet po 40. roku życia. Hygeia Public Health. 2015;50,1:219-225.

23. Gugała B., Głaz J., Drelich A. Zapotrzebowanie na edukację w zakresie profilaktyki nietrzymania moczu u kobiet. Przegląd Medyczny Uniwersytetu Rzeszowskiego i Narodowego Instytutu Leków w Warszawie. 2011; 3: 340-347. 